\title{
Dido’s Defense: Joachim Du Bellay's Bid for Female Patronage
}

\author{
BETH LANDERS
}

Washington University in St. Louis

This article argues that French poet Joachim Du Bellay's interest in the Dido figure and his unusual ventriloquizing of female characters are connected to his practice of cultivating female patrons. Du Bellay's occasional poems, long ignored by scholars, suggest the impact that these patrons had on Du Bellay's career. Although his writing for women is inconsistent with recommendations made in the Deffence et illustration de la langue francoyse, $D u$ Bellay's work for female patrons nonetheless allowed him to fulfill many of his early poetic ambitions.

Cet article avance que l'intérêt du poète français Joachim Du Bellay pour le personnage de Didon ainsi que l'inhabituelle ventriloquie de ses personnages féminins sont liés à sa recherche de mécènes féminins. Les poèmes de circonstance de Du Bellay, longtemps ignorés par la recherche, suggèrent que ses mécènes ont eu un impact sur sa carrière. Bien que son écriture pour des femmes soit en contradiction avec les recommandations contenues dans $s a$ Deffence et illustration de la langue francoyse, ce travail pour des clientes féminines lui a permis de concrétiser plusieurs de ses premières ambitions poétiques.

$\mathrm{K}$

athleen Wilson-Chevalier recently noted that female literary patronage in the Renaissance has received less attention than female patronage of the visual arts in this and earlier periods. ${ }^{1}$ She points out that the studies of female literary patronage that do exist have primarily focused on manuscripts commissioned by women before the age of printing, and secondarily on the way that women supported the production of printed books. Yet other studies have analyzed dedications to female patrons and the role that royal women and female elites played in literary culture. ${ }^{2}$ In one of these, Claudie Martin-Ulrich offers an explanation for the difficulty of tracing female literary patronage: she asserts that the relationship between writers and royal women was not fundamentally economic, but rather based on intellectual and spiritual

1. See Kathleen Wilson-Chevalier, ed., Patronnes et mécènes en France à la Renaissance (Saint-Etienne: Publications de l'Université de Saint-Etienne, 2007), 3.

2. See Susan Broomhall, "Au-delà de la cour: patronnes et mécènes du manuscrit à l'imprimé," in Wilson-Chevalier, ed., 39-52. 
affinities that were mutually satisfying to artist and patroness. ${ }^{3}$ This is the direction this article takes. It proposes that in the absence of correspondence or financial records that would give proof of patronage, a possible way to identify connections between poets and female patrons is to examine occasional poems, an often unexamined segment of an author's oeuvre. Three poems in which French poet Joachim Du Bellay ventriloquizes two women at the court of Henry II-Diane de Poitiers and Marguerite de Lustrac-provide material for a case study. They reveal the extent to which Du Bellay, by both disposition and strategy, attempted to connect with a female audience by combining the writing practices of an older generation of poets represented by Mellin de Saint-Gelais and Clément Marot with recommendations put forward in his well-known La Deffence et illustration de la langue françoyse (1549).

This may seem surprising, and for two reasons. First of all, apart from numerous studies concerning Du Bellay's connection to the erudite Marguerite de France/Savoie, sister to Henry II, Du Bellay's relationships to other court ladies and the poetry they inspired have received little attention. ${ }^{4}$ This may be due to the occasional nature of much of Du Bellay's writing for women and the reluctance of scholars to engage with such poetry, traditionally considered trivial. ${ }^{5}$ Recent scholars have tended to focus on the aesthetic, formal, or

3. See Claudie Martin-Ulrich, La persona de la princesse au XVI' siècle; personnage littéraire et personnage politique (Paris: Honoré Champion, 2004), 294.

4. Biographies of Du Bellay and of Marguerite de Savoie provide information about their relationship. See Henri Chamard, Joachim Du Bellay 1522-1560 (Lille: Travaux et Mémoires de l'Université de Lille, 1900), Roger Peyre, Une Princesse de la Renaissance. Marguerite de France, duchesse de Berry, duchesse de Savoie (Paris: Emile Paul, 1902), and Winifred Stephens, Margaret of France, Duchess of Savoy 1523-1574 (London: John Lane, 1912). The relationship between Du Bellay and Marguerite is also discussed in an article by Charles Béné, "Marguerite de France et l’œuvre de Du Bellay," in Culture et pouvoir au temps de l'Humanisme et de la Renaissance, ed. Louis Terreaux (Geneva: Librairie Slatkine, 1978), 223-40, and in a second article by Jean-Claude Margolin published in the same volume, "Une princesse d'inspirations érasmienne: Marguerite de France, duchesse de Berry, puis de Savoie," 155-77. See also Marie Dominique Legrand, "Explication du sonnet 176 des Regrets de Joachim du Bellay," L'Information littéraire 39.2 (1987): 84-88, and Catherine Magnien Simonin, "L'unique Marguerite de nostre âge et Les Regrets," in Du Bellay, Actes de Colloque International d'Angers, May 26-29, 1989, ed. George Cesbrun (Angers: PU d'Angers, 1990), 131-47. In past decades, a few studies have appeared on occasional poems that Du Bellay wrote to men: particularly the king and powerful men in the social elite. See David Hartley, A Critical Edition of the Circumstantial Verse of Joachim Du Bellay (Lewiston, NY: Edwin Mellen Press, 2000).

5. Henri Chamard, an important voice in early twentieth-century Du Bellay studies, tended to dismiss Du Bellay's occasional poems to women, commenting that Du Bellay's writing for the Maréchale of 
historical and political aspects of Du Bellay's work, rather than on his identity as a courtier and its possible impact on his writing. ${ }^{6}$ Furthermore, in the Deffence Du Bellay himself criticizes the older generation of "Pöetes Courtizans" who participate "aux Jeux, aux Baings, aux Banquetz."7 Rather than spend time in "les sumptueux palais des Seigneurs, et Cours magnifiques des Princes entre les Dames et Damoizelles," he maintains that poets should immerse themselves in "doctes Etudes, et riches Byblyotheques des Sçavans." "The Deffence thus suggests a male ideal of literary production, best pursued away from the effeminate circles of "Dames et Damoizelles." It also polemicizes against traditional French forms of poetry such as rondeaux, ballades, and chansons. ${ }^{10}$ Instead, the Deffence advocates for a high conception of poetry, produced by learned scholars and inspired by great classical writers whom Du Bellay says should be imitated rather than translated. ${ }^{11}$

Yet the Deffence is not always a coherent document and Du Bellay's actual practice often diverges from assertions he makes in the treatise. ${ }^{12}$ For example, although he criticized the feminine and effeminizing court culture in which popular forms and occasions ruled artistic production, he also sought proximity

Saint-André was of little consequence. "[...] j’y verrais volontiers un de ces jeux d'esprit subtils et précieux où se complaisait le goût de lépoque, et qui d’ailleurs ne tiraient pas à conséquence." Chamard's comment can be found in volume 5 of his edition of Du Bellay's collected works: Joachim Du Bellay, Oeuvres poétiques (Paris: Librairie Nizet, 1987), 396.

6. See Marc Bizer, Homer and the Politics of Authority in Renaissance France (Oxford: Oxford University Press, 2011), 81-100; Corinne Noirot, "Entre Deux Airs" Style simple et ethos poétique chez Clément Marot et Joachim Du Bellay (1515-1560) (Paris: Hermann, 2013); and articles by Isabelle Fernbach, Corinne Noirot-Maguire, and Todd W. Reeser in Virgilian Identities in Renaissance France, ed. Phillip John Usher and Isabelle Fernback (Cambridge: Brewer, 2012).

7. "court poets," "in games, baths, and banquets." All citations of the French text come from Jean-Charles Monferran's edition: Joachim Du Bellay, La Deffence et illustration de la langue françoyse (Geneva: Droz, 2008); here, p. 143. All English translations of the text are mine.

8. "the sumptuous palaces of great Lords, and the magnificent courts of Princes amid the Ladies and young noble women," "[...] learned studies, and rich scholarly libraries" (167).

9. See Robert Griffin's description of the male nature of the Pléiade and its influences in Coronation of the Poet: Joachim Du Bellay's Debt to the Trivium (Berkeley: University of California Press, 1969), 7-11.

10. "rondels, ballads, [...] songs" (132).

11. See book 1, chapter 5 of the Deffence.

12. See Chamard, Joachim Du Bellay 1522-1560, 223-24; V. L. Saulnier, Du Bellay (Paris: Hatier, 1968), 51; and Monferran, ed., Deffence, 36, 39-40. 
to the court, a milieu that ultimately shaped his poetics. Despite his criticism of poets who addressed court ladies and participated in banquets and games, $\mathrm{Du}$ Bellay nonetheless wrote several poems in the voices of noble women that were used as part of entertainments at court. And although he initially advocated imitating rather than translating great classical and foreign texts, he eventually produced several translations, including three that centre on the figure of Dido, who will turn out to be central to my undertaking.

The bias against Du Bellay's occasional poetry has obscured the full extent of his involvement with female patrons. Beyond his special relationship with Marguerite de France/Savoie, and perhaps because of it, he developed a sustained affinity for the female audience at court, based in part on a shared concern about the damaging effects of gossip and the need to manage one's reputation. Du Bellay's increasing skepticism about the king and the monarchy, combined with his celebration of those who serve as "seconds," is likely to have led him to the conclusion that a female network would be equally or more desirable than a male one. ${ }^{13}$ In two cases when he was absent from court, due first to illness (1551-52) and then to a four-year sojourn in Rome (1553-57), he sought to reconnect with the courtly milieu by strategically appealing to a female audience. He made this appeal by defending female reputations against wounding rumours and false reports. Before these attempts to re-integrate into the French court, his earliest work gives evidence of his own struggles with the gossip economy and launches both a theme and a defensive mode of writing to which he will return many times over the course of his career.

\section{Du Bellay's entry into the court economy}

In his first collections, published in March 1549 (La Deffence, L'Olive, Vers Lyriques), Du Bellay seems securely ensconced in a small brotherhood of school friends, the cohort of poets known today as the Pléiade. Literary historians tend to identify Du Bellay's friend Pierre de Ronsard as the Pléiade’s leader, but it was Du Bellay—the last member to join the group and the least educated — who

13. For discussion of Du Bellay's ambivalence about the French monarchy, see Bizer, Homer and the Politics of Authority; for illustration of his appreciation of "seconds," see Corinne Noirot in Entre Deux Airs and Corinne Noirot-Maguire, "At the Helm, Second in Command: Du Bellay and La Mort de Palinure," in Usher and Fernback, ed., 189-212. 
was the first to publish and give voice to the Pléiade's ideals in the Deffence. ${ }^{14}$ Du Bellay's illustrious family name and the connections it guaranteed may explain why Du Bellay published before Ronsard and his peers: the Deffence is dedicated to his older male relative, the cardinal Jean du Bellay, who was a close advisor to the king and whose name guaranteed an attentive reception. The cardinal seems to have been Du Bellay's sole option for patronage in early 1549 , because the other two collections that appeared in the same year have no named dedicatee: the love sonnets in l'Olive are dedicated "a sa dame" and the Vers Lyriques only address a general "lecteur." ${ }^{15}$ The Vers, however, do contain individual poems addressed to Du Bellay's intimates, his friends and neighbours. The named dedicatees of poems are all men, and taken as an aggregate they point to the male nature of Du Bellay's social network at the time. The poems treat the pleasures and misfortunes of life, nature, and the passage of time. Neither jealousy among poets nor gossip at court figure as a topic in these early verses. To the extent that Du Bellay writes about the question of reputation, it is in terms of the poet's quest for the "laurier immortel" (immortal laurel). ${ }^{16}$ For example, he addresses a piece to the poet Jacques Bouju, titled "De l'immortalité des poëtes," in which he expresses confidence that his poetry will carry his name into posterity. ${ }^{17}$ Thus, in March 1549, Du Bellay's collections convey the impression of a poet who writes securely and confidently within a circle of male family members and friends.

Only a few months later, however, when Du Bellay publishes his fourth collection, the Recueil de Poésie in November 1549, he has clearly begun to worry about his reputation. He seems less confident and more defensive, aware of how his poetry may be received by a wider audience and how success may foster envy among friends. The opening verse, "A sa lyre," closes with the following verse:

\section{See Chamard, Joachim Du Bellay 1522-1560, 94-95.}

15. Critics have long speculated on the identity of the "dame" to whom the Olive is dedicated. Charles Béné has made the persuasive case that it was Marguerite de France, because her emblem was an olive branch. See Bénés "Marguerite de France et l'Oeuvre de Du Bellay," Culture et pouvoir au temps de l'Humanisme et de la Renaissance, ed. Louis Terreaux (Geneva: Librairie Slatkine, 1978), 226.

16. All citations from the Olive and the Vers Lyriques refer to Daniel Aris and Françoise Joukovsky's edition: Joachim Du Bellay, Euvres poétiques, vol. 1 (Paris: Bordas, 1993); here, 17. English translations are mine.

17. Aris and Joukovsky, ed., 114 (sonnet 13). 
Il ne fault que l'envieux die

Que trop hault tu as entrepris

Ce qui te fait ainsi hardie,

C'est que les choses qu'on dedie

Au temple, sont de plus grand pris. ${ }^{18}$

Du Bellay clearly thought he might be criticized for over-reaching (aiming "trop hault") in this new volume. He is newly conscious of an envious other who may not be supportive of his new writing project and targeted audience.

The Recueil is dedicated to Princess Marguerite, sister to Henry II, and contains odes not only to Marguerite but to the king, his wife Catherine de Medici, and other men and women at court. This is the most elite social group possible, much more prestigious than most of the male figures he addressed a few months earlier in the Vers Lyriques. The exact circumstances of $\mathrm{Du}$ Bellay's first connection with Marguerite are not clear, but it seems that the literary princess had read or heard of the Deffence and asked to meet him in the summer of $1549 .{ }^{19}$ As the first member of the Pléiade to appear in print and to be acknowledged by an important member of the royal household, Du Bellay may have suffered jealous sentiment both from more established court poets and from his young peers, particularly Ronsard. In response, he seeks to neutralize criticism of the new volume from the very first verse.

In this same Recueil he writes another verse to the poet Bouju, titled "Les conditions du vray poete," in which he asserts that the true poet is immune to feelings of envy, which are personified in the figure of an old woman: "La vieille au visaige blesme / Jamais grever ne le peult, / Qui se tormente elle mesme, / Quand tormenter elle veult." ${ }^{20}$ Here, in late 1549, as he moves closer to court circles and becomes more aware of how this could provoke the envy of fellow poets, Du Bellay nonetheless still wants to assert an idealized vision of poetry.

18. "The envious should not say / That you have aimed too high / What gave you such courage / Is that all that is dedicated / at the temple, is of the highest value" (123;11-15). All citations from the Recueil come from the first volume of Daniel Aris and Françoise Joukovsky's edition. Citations give page and then line numbers, separated by a semi-colon. Translations are mine.

19. See Saulnier, 53-54.

20. "The old woman with the pale face / can never strike / [because] she torments herself / when she wants to torment others" $(155 ; 13-16)$. 
He maintains that true poets are untouched by base motives and low emotions such as envy.

In 1550, when Du Bellay publishes a second, expanded edition of the Olive, jealousy is a topic that is treated more expansively. This volume, like the Recueil, is also dedicated to Princess Marguerite. Here, Du Bellay includes a new series of sonnets in which the poet/lover contends with jealousy and false reports. These sonnets are modelled after Italian ones and the sentiment is not original to Du Bellay, but the newly introduced themes of jealousy and false reports are an important addition to the collection. The first in the series, sonnet 98 , is constructed in hypotheticals, and the poet addresses rumours spread by an unidentified male rival: "S'il a dit vray / seiche pour moy lombrage / De l'arbre sainct" but "S'il a menti, la blanche main d'yvoire / Ceigne mon front des fueilles que j'honnore." ${ }^{21}$ The roles of lover and poet meld in this sonnet: if the rumours are true, the poet concedes that his inspiration may be taken away as punishment, but if the rumours are false, he hopes to be crowned with laurels and led forward by the shining eyes of his sonnet lady. In sonnets 99 and 100, jealousy is personified once again by an old woman who is accused of spreading false rumours that damage the poet's relationship with his lady.

These three sonnets are later followed by an elegy titled "Contre les envieux poetes: A Pierre de Ronsard," in which a sense of male rivalry, attached to poetry rather than love, becomes more fully expressed. Du Bellay responds to critics he describes as clowns or mocking carnival figures, "Mômes," who should stop sniping at his poetry and accusing him of imitating Ronsard: "Or cessent donques les Mômes / De mordre les ecriz miens." ${ }^{22}$ Their biting or sniping (mordre) becomes an increasingly constant preoccupation for $\mathrm{Du}$ Bellay-the envy of other court poets-as does his competition with Ronsard. In this poem, he clearly tries to distinguish himself from his friend and rival poet by asserting that while Ronsard may be the prince of odes, Du Bellay

21. "If [my rival] spoke the truth / dry for me the shade / of the holy tree" but "if he lied, [may] the ivory white hand / fasten the leaves that I worship around my brow" (sonnet 98; 1-2, 9-10). Translations of the Olive are mine. All citations from the Olive come from Daniel Aris and Françoise Joukovsky's edition: Joachim Du Bellay, Oeuvres poétiques, vol 1. (Paris: Bordas, 1993). Citations give sonnet then line numbers.

22. "Thus the critics stop / mocking my writing" (46; 54-55). Translations are mine. All citations-page and line numbers-from "Contre les envieux poetes" are from the Henri Chamard edition, Oeuvres poétiques, vol. 4 (Paris: Hachette, 1919). 
himself is master of the sonnet form, which he claims to have introduced to France. While he is careful to praise Ronsard and other poets, Du Bellay also defends what he feels to be his own original contributions to the new French poetry.

This is to say that over the course of 1549 and 1550, Du Bellay's poetry reflects his entry into the court economy. He developed from a young and naïve poet who wrote a dashing manifesto and supportive odes to his male friends into a creature at court who addressed pieces to its most elite members, particularly Princess Marguerite. His reputation grew beyond a circle of intimates. This visibility raised the stakes on everything that he wrote and published; as he grappled with public opinion, the topics of jealousy and rumour increasingly appeared in his work. His career was taking off, but he suddenly fell ill and was confined to his bed, far from the court, for at least a year. ${ }^{23}$

\section{Dido's defense}

Given the anxieties about professional jealousy and competition that $\mathrm{Du}$ Bellay had begun to express in 1550, it is possible to imagine that the hiatus imposed by his illness would have caused him considerable concern about lost opportunities to write and network at court. In 1552, when Du Bellay's health was re-established, he published a series of three translations of Latin texts that all feature the story of Dido, the widowed queen of Carthage who had an affair with the Roman Aeneas and committed suicide when he abandoned her. The first of these translated texts is book 4 of Virgil's Aeneid, which is relatively critical of the Dido character for not remaining faithful to her dead husband, Sychaeus. The second is a translation of letter 7 from Ovid's Heroides, a fictional letter written by Dido to Aeneas immediately before her suicide. The third translation is of a fourteen-line epigram attributed to Ausonius in which Dido defends her honour and complains about Virgil's inaccurate representation of her life. ${ }^{24}$

\section{See Saulnier, 16.}

24. Many scholars today doubt that the original Latin epigram was actually written by Ausonius. See Michel Magnien's comments in the recent edition of Du Bellay's Oeuvres completes, book 3, 1551-53 (Paris: Classiques Garnier, 2013), 388-38. For pragmatic reasons I will continue to refer to Ausonius as the author. 
Du Bellay's decision to work on the Dido story has been attributed to aesthetic and linguistic motivations, but I would like to suggest that it may have stemmed in part from Du Bellay's personal identification with the queen's struggle to control her reputation-as we have seen, he became increasingly preoccupied with the question of controlling his own public reputation in 1549 and $1550 .{ }^{25}$ The decision to translate the Dido texts is also likely to have been a shrewd bid to reconnect to a female audience. Since Du Bellay's first success at finding patronage before his illness had come from Princess Marguerite, he may have calculated that the Dido story was a means to regain visibility with women at court after his illness. While the volume containing the translations is dedicated to the humanist Jean de Morel, the preface makes warm mention both of Jean's scholarly wife, Antoinette de Loynes, and of Princess Marguerite. ${ }^{26}$ Marguerite's grandmother, Louise de Savoie, had commissioned a manuscript copy of Octavien de Saint-Gelais's initial French translation of the Heroides some fifty years earlier and its female protagonists appear to have made it popular among female audiences. ${ }^{27}$ Both Marguerite and Antoinette were the sort of learned women who would have appreciated the literary work required by the Dido translations, but the content of the three texts would have been broadly appealing. By presenting the three Dido texts together, Du Bellay created an opportunity for courtly debate, among women or mixed company,

25. For a general explanation of Du Bellay's interest in the Dido figure and his translation of Ovid, see Jean-Pierre Néraudau's article, "Traduction et création chez Du Bellay, l'exemple de la 'Complainte de Didon à Enée prinse d'Ovide," in La Naissance du monde et l'invention du poème, ed. Jean Claude Ternaux (Paris: Champion, 1998), 369-85. For explanations of all three Dido texts, see Magnien's introductions to the three Dido translations in Du Bellay's Oeuvres completes (2013), 359-68, 380-84, 388-89. See also Todd W. Reeser's article, “Du Bellay's Dido and the Translation of Nation," in Usher and Fernback, ed., 229. Reeser suggests in passing that Du Bellay identifies with the Dido character.

26. Du Bellay's last two publications before his illness had been dedicated to Marguerite: the 1549 Recueil de Poésie and the second edition of Olive in 1550. Du Bellay alludes to these dedications in the preface to the translation when he invokes "celle tant rare perle \& royale fleur de Princesses, l'unique MARGUERITE de nostre âge: au divin esprit de laquelle est par moy des long tems consacré tout ce qui pourra jamais sortir de mon industrie." See Henri Chamard, ed., Oeuvres poétiques (Paris: Librairie Droz, 1931), 6:247-48. For an account of Du Bellay's relationship with Jean de Morel and his wife and daughters, see Philip Ford's article, “An Early French Renaissance Salon: The Morel Household," in Renaissance and Reformation 28.1 (2004): 9-20.

27. See Mary Beth Winn, "Louise de Savoie, ses enfants et ses livres: du pouvoir familial au pouvoir d'état," in Wilson-Chevalier, ed., 254-56. 
on the different versions of the story and their varying degrees of sympathy for the Dido character. The translations might be seen as a new installment in the querelle des femmes, one in which a chivalrous Du Bellay appears to side with the femme..$^{28}$ In one of the many palinodes of his career, we thus see Du Bellay shift from polemicizing against translation and female circles in 1549 to writing a series of translations in order to access female circles in 1552.

In the preface to the published volume, Du Bellay explains why he chose to present these three particular texts together in translation:

Je retourne à la translation du quatriesme de l'ENEIDE, que j'ay accompagnée d'une complaincte de Didon à Enée, immitée sur Ovide: ce que j'ay faict, tant pour la continuation du propos, que pour opposer la divine magesté de l'ung de ces aucteurs à l'ingenieuse facilité de l'autre. J'ay encore adjousté ung epigramme d'Ausone, declarant la verité de l'hystoire de Didon, pour ce qu'il me sembloit inique de renouveler l'injure qu'elle a receu par Vergile, sans luy reparer son honneur par ce qu'autres ont escrit à sa louange. ${ }^{29}$

Du Bellay says that he translates both Ovid and Virgil to contrast their styles-the divine majesty of the epic Virgil is set against the ingenious ease of Ovid. The final piece by Ausonius, however, is included not for its style but for its defense of Dido, whom Du Bellay thinks was wronged in Virgil's version. ${ }^{30}$

28. For a concise account of the querelle des femmes, see Julie D. Campbell's chapter in The Ashgate Research Companion to Women and Gender in Early Modern Europe, ed. Allyson M. Poska, Jane Couchman, and Katherine A. McIver (Aldershot: Ashgate Publishing, 2013), 361-79.

29. "I return to the translation of the fourth book of the Aeneid, accompanied by a complaint from Dido to Aeneas, an imitation of Ovid: which I did, as much for thematic continuity as to contrast the divine majesty of the first author to the ingenious ease of the second. I added an epigram by Ausonius, which declares the truth of Dido's story, because it seemed to me iniquitous to renew the insult she received from Virgil without restoring her honour with the praise that others have written on her account" (252-53). The translation is mine. All citations of Du Bellay's Dido translations come from Chamard's edition of Du Bellay's Oeuvres poétiques, vol. 6 (1931).

30. Du Bellay here joins a tradition of authors who defend Dido against her representation in Virgil. For example, see a discussion of Boccaccio's (and to a lesser extent Petrarch's) defense of the queen in Craig Kallendorf's article, “Boccaccio's Dido and the Rhetorical Criticism of Virgil's Aeneid," Studies in Philology 82 (1985): 401-15. See also Phillip Hardie's chapter on the Dido story in The Last Trojan Hero: 
As Virgil presents the story in the Aeneid, Dido's resolve to remain faithful to her dead husband is overcome when she and Aeneas take refuge from a thunderstorm in a cave. Her relationship with Aeneas is not the sole cause of her downfall, however. Instead, it is rumour that brings her down, despite the fact that "Dido / Is unconcerned with fame, with reputation, / With how it seems to others." ${ }^{31}$ After the lovers' passionate encounter in the cave, Virgil explains: "[...] Rumor goes flying / At once, through all the Libyan cities, Rumor / Than whom no evil was ever swifter."32 These rumours of Dido's affair with Aeneas reach King Iarbus, a suitor who had earlier been rejected by the queen after the death of her husband. In his jealousy, Iarbus complains to Jove that it is unfair for Dido to reward Aeneas with her affections after having rejected his own advances. Jove is sympathetic, and he intervenes and causes Aeneas to abandon Dido, which leads to her suicide. Virgil's story thus presents a woman who suffers dire consequences from rumours that circulate about her character, provoke a jealous lover, and lead to her abandonment by Aeneas. ${ }^{33}$

The Ausonius piece, written centuries later, offers a representation of Dido that aligns with those found in historical accounts rather than epic ones, casting doubt on Virgil's version of the story. It denies that Aeneas even landed in Carthage, and presents Dido claiming that she committed suicide not because she was abandoned by Aeneas, but because she wanted to escape from the rapacious Iarbus and preserve her honour:

Tel corps javoy, non l'impudique esprit

Qui feintement par Vergile est descript:

Car onq'Enée, onques le nefs Troyennes

Ne prindrent port aux rives Libyennes.

\footnotetext{
A Cultural History of Virgil's Aeneid (London: I.B. Taurus, 2014), 51-76. Hardie observes that beginning with the Roman author Macrobius, the "defence of Dido becomes something of a commonplace" (53).

31. The Aeneid of Virgil, trans. Rolfe Humphries (New York: Charles Scribner's Sons, 1951), 92. All citations of the Aeneid in English in the main text come from this edition.

32. Humphries, ed., 93.

33. Hardie writes about the central importance of Rumour: "The question of how to perceive, and what to say about Dido (and Aeneas) is embodied within the text in the monstrous personification of Fama, 'Rumour,' who spreads a slanderous version of the love affair of Dido and Aeneas after their union in the cave. Fama in Latin can also mean poetic or historical 'tradition' and the personification is also an embodiment of the vagaries of reception and tradition" (52).
} 
Mais pour füir de Iärbe la fureur,

Mon estomac pudique n'eut horreur

Du chaste fer, dont je fu' transpersée,

Non d'une rage ou amour offensée.

De telle mort me plaist bien le renom,

Puis qu'en vivant je n'ay blessé mon nom. ${ }^{34}$

Although Virgil's text states that Dido is unconcerned with fame and reputation, at least in the cave episode, Ausonius's heroine is explicitly concerned with her reputation. She suggests that Virgil's version is pure fiction, a false rumour of the literary kind, and later berates Virgil directly:

Qui tavoit donq', ô Vergile, incité

D’estre envieux sur ma pudicité?

Croyez, lecteurs, cela que les histoires

Ont dict de moy: non les fables notoires

De ces menteurs, qui d'art laborieux

Chantent l'amour des impudiques Dieux. ${ }^{35}$

Du Bellay writes that he includes Ausonius's version of the Dido story in order to "repair Dido's honour," and he thus implies criticism of Virgil's account. He clearly sides with the queen in this literary querelle. He neither blames nor praises Ovid's version of the Dido story in the Heroïdes, however, except to comment on the "ingenious ease" of Ovid's style. If Ovid's letter escapes the criticism that Du Bellay dealt to Virgil's text, perhaps it is due to being written in Dido's own voice: Ovid conveys her story in a first-person narrative just as Ausonius does, rejecting Virgil's use of a third-person narrator.

34. Chamard, ed., Oeuvres Poétiques (1931) 6: 331; 3-12: "Such a body I had, not the shameless spirit / that is falsely described by Virgil: / For never did Aeneas nor the Trojan ships / ever set anchor on Libyan shores. / But in order to flee Iarbus's fury, / my chaste stomach had no fear of the chaste steel, by which I was pierced, / Not by rage or by spurned love. / I am proud to be known for such a death / Because when alive I never did anything to damage my good name."

35. Chamard, ed., Oeuvres Poétiques (1931) 6: 332; 15-20. "Who incited you, o Virgil / To envy my chastity? / Believe, readers, what history / has said of me: not the notorious fables / Of these liars, who with laborious art / Sing the love of unchaste Gods." 
When Du Bellay translates Virgil into French, he uses ten-syllable lines of rhymed couplets-a heroic form in French poetry and thus not a surprising choice; the epic Latin form is replaced by an epic French form. The form Du Bellay chooses for his translation (or "imitation") of Ovid is more surprising and may be linked to the text's first-person point of view and the impression it gives of hearing Dido directly. Du Bellay does not translate Ovid's letter into an epistle in French, which would have been an option, but into a song form that he had also used for poems written in his own voice. ${ }^{36}$ Dido's persecution by rumours aligns with Du Bellay's own preoccupation with gossip at court. Using the same song form for his own voice and for Dido's, Du Bellay points to his equation of the two. As a result of shifting to a song form, Du Bellay eliminates most references to writing that were a logical part of the original Ovidian letter and he underscores the text's comparison of Dido's complaint to the song of a dying swan. For Du Bellay, the appropriate form for female complaint appears to be a song rather than a letter, and the woman is a swan, just as the poet (following classical tradition) is so frequently compared to a swan throughout Du Bellay's work. ${ }^{37}$ Dido and the poet are both creatures who sing; their intervention in the world is based on voice rather than action.

When writing in his own voice, Du Bellay adopts this form in three occasional poems to male friends and patrons. He first uses it in "Les Louanges d'amour," a poem he dedicated to a neighbour, René D'Urvoy, in the 1549 Vers Lyriques. He then recycles it in two poems written after the Dido translation: "Hymne de Santé" to Robert de la Haye in 1552 or 1553, and his praise poem to Louis de Saint-Gelais, seigneur de Lanssac-“Au Seigneur de Lansac,

36. For a discussion of this form, composed of six-line stanzas that alternate between lines of seven and three syllables, see Paul White's excellent book Renaissance Postscripts: Responding to Ovid's Heroides in Sixteenth-Century France (Columbus: Ohio University Press, 2009), 157-58. White mentions that the song form was used earlier by Marot and suggests that this may indicate that Du Bellay had reconsidered previous criticism of Marot. Corinne Noirot, in Entre deux airs, has also observed continuity between Marot's work and Du Bellay's.

37. See Françoise Joukovsky's La gloire dans la poésie française et néolatine du 16e siècle (Geneva: Droz, 1969), 338-39, for a discussion of the swan figure in Du Bellay and the Pléiade. Additionally, although she writes about the English tradition, it is interesting to consider Elizabeth Harvey's assertion that "It could be argued that the complaint, particularly the complaint voiced by the seduced and abandoned woman, which descends ultimately from Ovid's Heroides and which flourished so pervasively in Renaissance (especially Tudor) England, is the paradigmatic ventriloquized text." Elizabeth Harvey, Ventriloquized Voices: Feminist Theory and English Renaissance Texts (London: Routledge, 1992), 140. 
Ambassadeur pour le roy a Rome"-probably written in late $1553 .^{38}$ In the first poem, Du Bellay celebrates de la Haye's return to health, and in the second he celebrates Lanssac's eloquence, his honeyed tongue. Du Bellay does not "lend a voice" or ventriloquize any of these men, who presumably can speak for themselves. In fact, we know that Lanssac speaks quite well, since it is his eloquence that provokes Du Bellay's encomium. In these three songs to male patrons, it is Du Bellay's voice that is poured into the metric mould that he uses to convey Dido's voice in his translation of Ovid-in each case his "je" addresses the patron's "tu."

It is worth noting that when writing to male patrons and adopting the voice of a fictional woman (Dido), Du Bellay does not hesitate to recycle the same metric form. After his return from Rome in 1557, however, when writing in the voices of real women living at court, he takes the time to create bespoke verses with metres tailored to the individual. He ventriloquizes the defense of court ladies in the same way that he gave voice to the Queen of Carthage in his translations of Ovid and Ausonius, but he creates individual forms that represent their voices in unique lengths, rhythms, and rhymes. This practice appears to be new to Du Bellay, but it aligns with the writing that an earlier generation of poets, embedded at court, produced for their patrons. It signals both $\mathrm{Du}$ Bellay's increased proximity to women at court upon his return to France in 1557 and a virtual retraction of earlier criticism of these poets in the Deffence.

\section{Lending a voice: Du Bellay's defense of Diane de Poitiers and Marguerite de Lustrac}

Besides Princess Marguerite, the woman whom Du Bellay cultivated most as a patron was Diane de Poitiers, the famous and powerful mistress of Henry II. ${ }^{39}$

38. These poems can be found in Chamard's 1987 edition of Oeuvres Poétiques, 5:264, 318.

39. Eleven poems to Diane appear in the eight volumes of Du Bellay's collected works begun by Henri Chamard and completed by Genevieve Demerson. See Joachim Du Bellay, Oeuvres Poétiques, ed. Henri Chamard, 6 vols. (Paris: Société des Textes Français Modernes, 1908-31), and Joachim Du Bellay, Oeuvres Latines, ed. and trans. Geneviève Demerson, vols. 7-8 (Paris: Librairie Nizet, 1984-85). The poems to Diane have infrequently been studied by literary scholars. They are cited in some of her biographies, and the poems that mention her chateau Anet have also been cited by art historians. See Jean Balsamo, "Les poètes d'Anet," Henri II et les arts, ed. Julia Fritsch and Hervé Oursel (Paris: L'Ecole 
Du Bellay appears to have written more poems for Diane than any other member of the Pléiade. ${ }^{40}$ Of the eleven poems that Du Bellay wrote for Diane, two are unusual because written in her own voice. This is unusual both in general and in Du Bellay's own corpus; Cathy Yandell, for example, has suggested that it is rare to find male poets in the French Renaissance who adopt female voices. ${ }^{41}$ Although Du Bellay produced many occasional poems, I know of only one other in which he adopts the voice of another person, and this occurs in another poem written for a woman: a song for Marguerite de Lustrac, the Maréchale de Saint André, for whom no other Pléiade poets seem to have written. ${ }^{42}$ For the most part, Du Bellay's occasional poems are addressed to or for their addressees-as in the poems to René d'Urvoy, Robert de la Haye, and Louis de Saint-Gelais-and they represent Du Bellay's own sentiments, expressed in his own voice, rather than that of someone else (as discussed above). This begs for further examination, particularly because I am unaware of any previous study of these three poems that ventriloquize women at the court of Henry II.

du Louvre, 2003), 417-25; Françoise Bardon, Diane de Poitiers et le Mythe de Diane (Paris: Presses Universitaires de France, 1963); Ivan Cloulas, Diane de Poitiers (Paris: Fayard, 1997); Philippe Erlanger, Diane de Poitiers (Paris: Gallimard, 17th ed., 1955).

40. I base this on the entry for Diane de Poitiers in the Table des noms compiled by Charles Marty-Laveaux in an appendix to his edited volume of the Pléiade poets. See Charles Marty-Laveaux, La Pléiade Françoise, Appendix, vol. 2, La Langue de la Pléiade, Additions.-Tables (Geneva: Slatkine Reprints, 1966), 557. Of the other Pléiade poets, Ronsard is second to Du Bellay in the number of poems he writes to Diane, followed by Jodelle and then Tyard.

41. See Cathy Yandell, "L'Amour au Féminin? Ronsard and Pontus de Tyard Speaking as Women," in Ronsard Figure de la Variété, ed. Colette H. Winn (Geneva: Droz, 2002), 65-83. In an additional analysis of male use of the female voice, Mireille Huchon argues that the female poet Louise Labé was in fact a fictional creature, created and ventriloquized by a network of male poets. She cites an Italian tradition of male poets writing verse under the name of courtesans, as well as a French tradition in Lyon of male poets adopting a female voice in the 1540s, in Louise Labé. Une créature de papier (Geneva : Droz, 2006), 267. Relatively more attention seems to have been paid to male authors who adopt female voices in early modern England. See Lynn Enterline, The Rhetoric of the Body from Ovid to Shakespeare (Cambridge: Cambridge University Press, 2000) and "Rhetoric, Discipline, and the Theatricality of Everyday Life in Elizabethan Grammar Schools," in From Performance to Print in Shakespeare's England (Basingstoke and New York: Palgrave Macmillan, 2006). See also Deborah Greenhut, Feminine Rhetorical Culture: Tudor Adaptations of Ovid's Heroides (New York: Peter Lang, 1988), and Harvey, Ventriloquized Voices.

42. Marty-Laveaux's Table de noms (593) shows that Du Bellay was the only Pléiade poet to write to the Maréchale de Saint-André. 
The songs for Diane and Marguerite de Lustrac appear to have been published for the first time in the 1569 posthumous edition produced by D'Aubert and Jean de Morel, the first collected edition of Du Bellay's works. This means that, as far as we know, they only circulated in manuscript form during Du Bellay's lifetime but were selected by his posthumous editors to be preserved in print. The ordering of poems in the 1569 edition suggests the social context from which they arose. The three songs in question are printed in the beginning of volume 2 in a series of other poems that also appear to have circulated in manuscript form during Du Bellay's life. They come after three odes and one sonnet written to Diane-all praise poems to the lady written in Du Bellay's own voice. The group of Diane poems is immediately preceded by an ode to the Prince of Melphe, a praise poem whose content suggests that it was delivered at a dinner with Melphe and others. ${ }^{43}$ The six Diane poems are immediately followed by the song mentioned above for Marguerite de Lustrac, titled "Chanson pour M. la Mareschale de S. A.," which Marty-Laveaux says was probably sung "dans quelque divertissement," meaning that it probably functioned as entertainment at court. ${ }^{44}$

The placement of the Diane poems between pieces for Melphe and the Maréchale suggests that Du Bellay's posthumous editors categorized them as social ones that were delivered in public - at a dinner perhaps, like the poem to the Prince of Melphe, or in some sort of entertainment at court, as in the poem to Marguerite de Lustrac. Here Du Bellay contributes to the jeux and banquetz that he rejected in the Deffence, but apart from the publishing context of these poems we have no other information to help us understand their origins. In all three poems, however, female complaint is expressed as a song and the female protagonist defends her honour against rumours that have circulated about her at court. ${ }^{45}$ They share this theme with Du Bellay's earlier poems about jealousy and with his Dido translations. While the themes are the same, the metric forms are not: each song is virtuosically differentiated for its recipient. A closer

43. The ode to the Prince of Melphe is unusual in its own right because it is one of the few Pindaric odes that Du Bellay ever wrote. It is a further example of how Du Bellay tailors the forms of his occasional poems to the recipients and occasions that he targets: he uses the Pindaric ode form for the Prince de Melphe but for no one else.

44. Marty-Laveaux, 549n24.

45. It is possible to wonder whether the songs were indeed sung, and whether the individualized forms correspond to different tunes arranged for the occasion. 
examination of these poems provides a sense of Du Bellay's proximity to Diane de Poitiers and Marguerite de Lustrac.

The "Chanson pour M. la Mareschale de S.A." is relatively short. It contains three dizains, the first eight lines of which contain seven syllables followed by two final lines of ten syllables each. In it, the Maréchale asserts her honest friendship for Antoine de Bourbon, the king of Navarre and husband of Jeanne d'Albret. ${ }^{46}$ She declares that she will ignore ugly gossip that circulates about her relationship with Antoine because her conscience is clear; she knows that her honour is intact:
Je laisseray donc parler
Ceux qui font de moy leur compte.
Un poinct me peult consoler,
Que ne puis recevoir honte:
De leurs langues ne me garde,
Ayant honneur soubs ma garde. ${ }^{47}$

This song, written in defensive mode, is followed by a very brief response poem from Antoine's wife, Jeanne d'Albret, who rather haughtily suggests that the Maréchale is exaggeratedly aggrieved about the rumours. The queen herself is confidently secure in her relationship with her husband. It is unclear whether the queen of Navarre wrote the response herself or whether Du Bellay wrote it for her.

The forms used in the two songs written for Diane de Poitiers differ both from each other and from the one created for the Maréchale poem. The first

46. Du Bellay corresponded with Jeanne d'Albret in a series of fourteen sonnets. These can be found, along with four sonnets that the queen wrote in response, in volume 2 of Henri Chamard, ed. Oeuvres Poétiques (1961), 219-32. Both Chamard and V. L. Saulnier propose that the sonnets were written before Du Bellay's 1553 departure for Rome; they were not published until 1561. In the final sonnet Du Bellay asserts that he has found favour with Jeanne and that she is a more divine patron than those who supported Virgil and Homer. The exact expression of her favour is not explained, however. For further information about the relationship between Jeanne and poets, see Nathalie Dauvois, "Jeanne d'Albret et les poètes de Marot à Pey de Garros," in Jeanne d'Albret et sa cour, ed. Evelyne Berriot-Salvatore, Philippe Chareyre, and Claudie Martin-Ulrich (Paris: Honoré Champion, 2004), 281-96.

47. Chamard, ed., Oeuvres Poétiques (1987) 5:397, lines 21-26. "I'll let speak / All who pay attention to me / One thing is able to console me / that I cannot be shamed: / I pay no attention to their tongues / Having honour on my side." 
song is titled "En la personne de ladicte dame." ${ }^{38}$ It is short, composed of seven sizains that alternate between eight and seven syllables. Diane speaks in the present tense and defines the perfection of her love, without explicitly naming the object of her affection. Presumably, it is Henry II. The poem asserts that time cannot alter Diane's love for the king any more than false rumours: "Le temps ne luy peut faire tort, / Encores moins le faux rapport /d'une langue ennemie" (lines 28-30). ${ }^{49}$ This allusion to "false reports" spread by hostile tongues at court suggests that Diane is refuting accusations that have circulated on her account. She says that her love is not evil, that it does not aspire to any ulterior reward, that she does not feel threatened by the beauty of other women or the encroachment of time: these are all likely rumours that targeted her relationship with the king. The word "fear" reappears three times: "une miserable peur ne tormente ma vie," "[mon amour] ne craint la desloyauté," "De qui me doy-je craindre." ${ }^{50}$ Each instance, however, is negated or expressed in the interrogative so as to prove that Diane has nothing to fear.

The piece ends with a stanza in which Diane discredits all those who spread rumours about her and suggests that they are so distant from her that they can neither know her true status nor damage it in any way: "Plusieurs me grondent de bien loing [...] Ils sont comme chiens qui de nuict / Abboyënt la Lune qui luit, / Et ne la peuvent mordre." ${ }^{51}$ If Du Bellay describes his detractors in 1550 as carnival figures who "mord[ent] les ecriz miens" (line 54), Diane's detractors are dogs who bark at the moon but cannot bite it ("mordre"). Like the short poem that Du Bellay wrote for the Maréchale de Saint-André, this Diane poem defends against rumours that question her reputation, the authenticity

48. Henri Chamard, Euvres poétiques (Paris: Librairie Nizet, 1987), 389-90. Chamard asserts that "ladicte dame" is Diane, because it follows poems explicitly addressed to her in the 1569 edition.

49. "Time cannot harm [my love] / Any more than the false report / of an enemy's tongue" (390; lines 28-30).

50. "[...] a miserable fear does not torment my life"; "[my love] has no fear of infidelity"; "Whom should I fear?" (390; lines 23-24, 25, and 33).

51. Chamard, ed., Euvres poétiques (1987), 390; lines 37-42: "Many growl at me from far away [...] They are like dogs who at night / Bark at the moon, / and cannot bite it." About this last line, Chamard cites Furetière, who explains that the expression abboyer à la lune means useless complaining about someone who is more powerful, combined with the expression tout chien qui abboye ne mord pas which means that not every threat is actually capable of causing much damage (390n1). The moon image also seems particularly apt for Diane, who was often represented as Diana, the moon goddess. 
of her love, and the health of her relationship with the king. Whereas the Maréchale de Saint-Andrés poem received a response poem from the queen of Navarre and appears to have been shared in some public way, there is no response published to the Diane poem and it is impossible to know whether it was shared with an audience, performed in public, or read in private. If there had been any response addressed to the poem, it is now lost.

In the second piece, titled "Chanson," Diane addresses her sad sighs, "tesmoings de ma pensee," during a separation from Henri II. ${ }^{52}$ It is longer than the first poem and is composed of fifteen decasyllabic huitains. Two different refrains used in the first fifteen stanzas are ultimately combined in the final stanza, symbolic perhaps of a resolution, a happy reunion that Diane desires with the king. Indeed, Henry II seems to be the audience for this song-which like the first poem asserts the perfection of Diane's love, once again via a series of negations, but also through a series of hypothetical "if-then" statements whose binary outcomes define the king's hold on Diane as one of life and death.

In the first stanza, Diane says that she is so overcome with emotion that she has neither "le parler ny les yeulx." ${ }^{53}$ Blind and mute, she first claims that if her sentiments be pure and tainted with "rien de lamour vicieux," then her sighs should be suppressed, or return to her, because she would no longer wish to die. ${ }^{54}$ The same refrain is repeated for eleven stanzas: "Tournez à moy, je ne veulx plus mourir." ${ }^{55}$ The refrain changes, however, in stanza 12, when Diane says that if "[...] par mort, ou par quelque disgrace / Par quelque envie, ou quelque faulx rapport / M’est denié l'heur de revoir sa face (Penser qui seul m'est pire que la mort)," then her sighs should climb to heaven and wait for her there "Montez au ciel, \& la-hault mattendez" because she would rather die. ${ }^{56}$ Here, once again, we find allusions to the false reports of court, envious rumours that attempt to disgrace Diane with the king and interrupt their relationship. Separation from the king is equal to death for Diane, who is already rendered

52. Chamard, ed., Euvres poétiques (1987), “Song” (5:391-95); “witnesses of my thoughts” (5:395, line 113).

53. Chamard, ed., Euvres poétiques (1987), 5:391; line 2: “[neither] spoken language nor sight.”

54. Chamard, ed., Euvres poétiques (1987), 391; line 4: "no vicious love."

55. Chamard, ed., Euvres poétiques (1987), 391, line 8: "Return to me, I no longer wish to die."

56. Chamard, ed., Euvres poétiques (1987), 394; lines 89-92: "But if by death, or by some disgrace / by some envy, or false report / I am denied the happiness of seeing his face once again / (The thought of which is the only thing worse than death for me)." 
half dead-blind and mute-as a result of malicious rumours. The final stanza summarizes Diane's situation: "si mon amour n'est point recompensee" she wishes to die, but if her honour and virtue are acknowledged by the king, then once again her sighs should "Tournez à moy, je ne veulx plus mourir." ${ }^{57}$ Diane's life, her will to live, thus depends on the solidity of her relationship to the king and on the honour of her reputation.

How can we understand these poems, which never appeared in print during Du Bellay's life and which are difficult to date? There may be some historical event that explains their content. In the case of the Diane poems, for example, Henri Chamard thought that the "Chanson" dated from late 1557 or 1558 , in which case it would have closely followed Henry II's affair with Nicole de Savigny and the birth of their illegitimate son-a relationship that is likely to have posed a threat to Diane and caused a rift between her and the king..$^{58}$ Other members of court may have tried to exploit the situation for political advantage, just as earlier in the decade Anne de Montmorency had fostered the king's affair with Jane, Lady Fleming in order to attenuate Diane's influence and increase his own hold on power.

Whatever the immediate social context of these poems, however, $\mathrm{Du}$ Bellay's ventriloquization of Diane and the Maréchale recalls the writing practice of an older court poet, Mellin de Saint-Gelais, who ventriloquized Henry II and his son, the Dauphin François, years earlier. ${ }^{59}$ We know that Henry commissioned Saint-Gelais to write a verse epistle to Catherine de Medici in his own voice-a letter in which Henry congratulates his wife on the birth of one of their children. While Du Bellay had criticized Saint-Gelais in the Deffence as one of the "Poëtes Courtizans" who were embedded in "les somptueux palais des Seigneurs, et Cours magnifiques des Princes entre les Dames et Damoizelles," the social model in which Saint-Gelais worked still obtained and courtiers may have wished to continue the practice of commissioning poems. Chamard believed that after his return from four years in Rome, Du Bellay

57. Chamard, ed., Euvres poétiques (1987), 395, line 115: "If my love is not returned" she wishes to die. 58. See Chamard, ed., Euvres poétiques (1987), 5:393n1.

59. See Mellin de Saint-Gelais, "Epistre du Roy, estant à Annet, à la Royne, estant demeuree à St. Germain en couche de Monseigneur d'Orleans, 1548 Fait promptement par le commandement dudit sieur," in Oeuvres poétiques françaises, ed. Donald Stone Jr., vol. 2. (Paris: Société des Textes Français Modernes, 1995), 264-68, as well as “Epistre de Monseigneur le Daulphin François, en l'eage de cinq ans au Roy Henry son père," 269-74. 
knew improved success at court from 1557 to 1559. Jeanne d'Albret's presence at court in both 1558 and 1559 makes it plausible that the Maréchale poem and Jeanne's response date from this period along with the Diane poems. ${ }^{60} \mathrm{It}$ thus is possible that Diane and the Maréchale commissioned these poems from Du Bellay, perhaps in an attempt to strategically manage gossip that circulated about them, just as Henry II commissioned the epistle from Saint-Gelais at a critical point in his marriage. If this is the case, then Du Bellay would have had to have close access to female circles at court, a proximity prepared by his early relationship with Princess Marguerite, his often-expressed sensitivity to the pressures of court society, his reworkings of the popular Dido story, and his defense of the queen in his 1552 translations. ${ }^{61}$

\section{Conclusion: Du Bellay's proximity to women}

Jean-Max Colard has written that Clément Marot's court poetry represents a "poetry of proximity." ${ }^{2}$ Although Marot belonged to the earlier generation of poets like Saint-Gelais who were rejected in the Deffence, Du Bellay too is very much a poet who seeks proximity. ${ }^{63}$ This is an additional key to understanding the poems to Diane and the Maréchale de Saint-André. Marc Bizer has already pointed to Du Bellay's desire for proximity in his reading of the sonnets in the Regrets as so many letters to the French court in which Du Bellay attempts to bridge the distance between Rome and France. ${ }^{64}$ Roman Jakobson notes Du Bellay's use of the conative function to address others in his poetry, which

60. See Chamard, ed., Euvres poétiques (1987), 5:396.

61. It should also be noted that in the Regrets, published in this same period (1558), seventeen of the last thirty-three encomiastic sonnets in the collection are dedicated to Princess Marguerite or her entourage. Marguerite remained Du Bellay's central female patron during this post-Rome period, as important to him or more than before he left for Rome. Writing for Diane de Poitiers and Marguerite de Lustrac represents an expansion of his relationship to women at court after his return from Rome.

62. Colard cites Norbert Elias's description of court society as one that has "une configuration où le plus grand écart social se manifeste dans la plus grande proximité spatiale." Jean-Max Colard, "Marot : parole de la proximité" in Clément Marot " Prince des poëtes françois». ed. Gérard Defaux and Michel Simonin, Actes du Colloque international de Cahors en Quercy 21-25 mai 1996 (Paris: Champion, 1997), 545-557, 550 .

63. Again, Noirot has recently written on the continuity between Marot's poetics and Du Bellay's. See note 36 , above.

64. See Marc Bizer, Les lettres romaines de Du Bellay (Montreal: PU de Montréal, 2001). 
can perhaps also be seen as an attempt to bridge distance between poet and audience. ${ }^{65}$ What could collapse distance more than actually writing as someone else, sharing their voice? Would writing as someone not be even closer than writing to them?

Paul White believes that Du Bellay's “imitation” of Ovid's Heroides number 7 distances the reader from the heroine because it literally "effaces the heroines' 'hand' in the work." ${ }^{66}$ Indeed, when changing the form from an epistle to a song, Du Bellay eliminates Dido's allusions to writing a letter in her own hand. But if we take into account sixteenth-century court culture and the practice of poets like Saint-Gelais who ventriloquized his patrons, I cannot agree with White. I believe that Du Bellay's song in Dido's voice is one that captures the intimacy of the heroine's predicament-Dido could be a lady of the court, ventriloquized by Du Bellay just like Diane and the Maréchale de Saint-André. Du Bellay, poet of proximity, seeks to collapse the distance between the ancient Dido and her sixteenth-century audience: she sings to them just as their fellow courtiers sing about the trials of gossip and love. Dido is a woman wronged, like Diane and the Maréchale. In fact, Dido is twice-wronged: first by Aeneas, and then by Virgil. Her honour is defended by Ovid and Ausonius, and much later by Du Bellay, who then lends his pen to the defense of Diane and the Maréchale.

At the same time, Du Bellay also bridges the distance between himself and Ovid, an admired predecessor. In the Deffence, when Du Bellay exhorts French poets to imitate classical models, he stresses the importance of knowing oneself and choosing models that are closest to one's personal style: "Avant toutes choses, fault que [le poète français] ait ce jugement de cognoistre ses forces et tenter combien ses Epaules peuvent porter: qu'il sonde diligemment son Naturel, et se compose à l'immitation de celuy, dont il se sentira approcher de plus pres." ${ }^{67}$ Following his "naturel," Du Bellay writes sonnets, like the Italians,

65. See Roman Jakobson, “'Si notre vie,' Observations sur la composition et structure des motz dans un sonnet de J. Du B.," Quaderno dell'Academia nationale dei Lincei, 1973; reprinted in Questions de Poétique (Paris: Le Seuil, 1973), 319-55.

66. See White, 186.

67. "Above all else, [a French poet] should have the discernment to know his own strengths and test how much his shoulders can bear: he must diligently probe his natural style and write in imitation of [the author] to whom he feels the closest." Monferran, ed., 130. 
and elegiac verse, like Ovid. ${ }^{68}$ Like Ovid and Ausonius, he offers womenfictional characters like Dido or living women like Diane and Marguerite de Lustrac-a voice to defend their honour and reputation against false rumours. On the other hand, Du Bellay defines Ronsard as a writer of odes, in the tradition of Pindar, and of epic, like Homer or Virgil, when he closes the preface to the 1552 translations by referring to "ce Pyndare François PIERRE DE RONSART [...] des labeurs duquel (si l'Apollon de France est prospere à ses enfentemens) nostre poëzie doit esperer je ne sçay quoy plus grand que l'Iliade." ${ }^{69}$ Favouring different models than Ronsard, models that appeal to a female audience, allows Du Bellay to carve his own place in the French pantheon. His affinity for this audience can be traced as he translated texts and engaged topics that mattered to women, defended their reputations, and tailored his poems to them in individualized metres. If cultivating Dames et Damoizelles and choosing to rework the traditional French song form contradicted certain recommendations found in the Deffence, Du Bellay nonetheless adhered to other precepts of his treatise, which encouraged the poet not only to imitate models that aligned with his "naturel" but also to "saccommoder à la saison et au lieu." ${ }^{70}$ Accommodating his youthful ideals to life at the French court, Du Bellay rose to the female occasion.

68. Although Du Bellay is not considered to have written epic, the genre nonetheless has been seen to inform his work. See Marc Bizer "From Lyric to Epic and Back: Joachim du Bellay's Epic Regrets," Modern Language Quarterly 71.2 (June 2010), 107-27. Bizer suggests that the Regrets may be a mock epic (126). Eric MacPhail traces allusions to Virgil in "Facilis descensus Averno: Retracing Aeneas's Steps in Du Bellay's Regrets," Viator 39.2 (2008), 227-43.

69. "this French Pindar PIERRE DE RONSART [...] from whose efforts (if the French Apollo is generous to his offspring) our poetry can expect something even greater than the Iliad." Chamard, ed., Oeuvres Poétiques (1931), 6:254-55.

70. "adapt oneself to the season and to the occasion." Monferran, ed., 164. 
